\title{
Karakteristik Penderita Glaukoma di Rumah Sakit Muhammadiyah Palembang Periode Januari 2017-April 2018
}

\author{
Ferzieza Dizayang \\ Universitas Muhammadiyah Palembang, ferziezadizayangg@gmail.com \\ Hasmeinah Bambang \\ Universitas Muhammadiyah Palembang, hasmeinah@fkumpalembang.ac.id \\ Mitayani Purwoko \\ Universitas Muhammadiyah Palembang,mitayani.dr@gmail.com
}

\begin{abstract}
Abstrak
Pada penyakit Glaukoma terjadi kerusakan saraf optik akibat terhambatnya aliran humour aqueous. Jika dibiarkan, glaukoma dapat menyebabkan kebutaan. Penelitian ini bertujuan untuk mengetahui karakteristik penderita glaukoma di Rumah Sakit Muhammadiyah Palembang periode Januari 2017-April 2018 berdasarkan usia, jenis kelamin, jenis glaukoma, keluhan utama, tekanan intraokular, dan riwayat penyakit sebelumnya. Penelitian ini menggunakan desain penelitian deskriptif retrospektif dengan pendekatan cross sectional menggunakan data rekam medis pasien glaukoma di Rumah Sakit Muhammadiyah Palembang periode Januari 2017 - April 2018. Jumlah populasi terjangkau adalah 82 subjek dan dengan perhitungan menggunakan rumus diperoleh besar sampel sebesar 45 subjek. Sampel diambil dengan teknik simple random sampling. Data dianalisis secara univariat dan ditampilkan dalam tabel distribusi frekuensi. Hasil penelitian ini menunjukkan glaukoma lebih banyak terdistribusi pada kelompok usia 40-64 tahun $(66,7 \%)$ dan jenis kelamin perempuan $(57,8 \%)$. Tipe glaukoma didominasi oleh glaukoma kronis $(57,8 \%)$, dengan keluhan nyeri mata $(37,7 \%)$, memiliki TIO lebih dari 21 $\mathrm{mmHg}(73,3 \%)$, dan memiliki riwayat penyakit sebelumnya $(60,0 \%)$.
\end{abstract}

Kata Kunci: glaukoma, tekanan intraokular, nyeri mata.

\begin{abstract}
Glaucoma is an eye disease in which the optic nerve damage is caused by barriers to discharge eyeball liquid production (Humor Aqueous). If left untreated, Glaucoma can cause blindness. This study aimed to determine the characteristics of glaucoma patients at Muhammadiyah Palembang Hospital in the period of January 2017-April 2018 based on age, gender, glaucoma type, main complaint, intraocular pressure, and previous disease history. This was a retrospective study with a cross sectional design using medical records of glaucoma patients at Muhammadiyah Hospital Palembang during January 2017-April 2018. The population of this study was 82 subjects and with the calculation using formulas obtained a sample size of 45 subjects. Samples were taken by simple random sampling technique. Data were analyzed univariately and displayed in a frequency distribution table. The results of this study indicated that glaucoma distributed mostly among peoples at 40-64 years old (66.7\%) and female gender $(57.8 \%)$. The type of glaucoma was dominated by chronic glaucoma $(57.8 \%)$, with eye pain as chief complaint (37.7\%), had IOP more than $21 \mathrm{mmHg}(73.3 \%)$, and had a previous disease history $(60.0 \%)$.
\end{abstract}

Keywords: glaucoma, intraocular pressure, eye pain.

\section{PENDAHULUAN}

Mata sebagai indra penglihatan sangat

penting bagi manusia. Fungsi mata yang sangat penting ini dapat terganggu akibat adanya gangguan yang berujung pada

kebutaan (Kemenkes RI, 2014). Menurut

World Health Organization (WHO),

kebutaan di dunia terbanyak disebabkan 
oleh katarak dan glaukoma (WHO, 2012). Berdasarkan hasil Riset Kesehatan Dasar tahun 2007, Sumatera Selatan berada di urutan ke-8 untuk kasus glaukoma di Indonesia dengan prevalensi 0,72\% (Kemenkes RI, 2015).

Glaukoma adalah suatu neuropati optik kronik dengan ciri adanya pencekungan diskus optikus, penyempitan lapang pandang, dan peningkatan tekanan intraokular (Riordan \& Whitcher, 2017). Risiko terjadinya glaukoma dikaitkan dengan jenis kelamin, usia, adanya riwayat glaukoma dalam keluarga, ras, dan adanya penyakit vaskular (Putri dkk, 2018).

Karakteristik penderita glaukoma di Poliklinik Mata Rumah Sakit Umum Pusat Sanglah Denpasar pada tahun 2014 didominasi laki-laki dari 42 kasus glaukoma primer, sebagian besar berada pada rentang usia 51-80 tahun, memiliki tekanan intraokular pada mata kanan ratarata $32,38 \mathrm{mmHg}$ dan mata kiri rata-rata 31,3 mmHg (Putri dkk, 2018). Karakteristik penderita glaukoma di Rumah Sakit Umum Daerah dr. Soedarso Pontianak seimbang antara laki-laki dan perempuan, sebagian besar berada pada rentang usia 60-69 tahun, didominasi oleh pasien dengan tekanan intraokular tinggi, sebagian besar tidak memiliki riwayat penyakit, dan didominasi oleh glaukoma yang unilateral (Asicha, 2011).
Tujuan dari penelitian ini adalah untuk mengetahui karakteristik penderita glaukoma di Rumah Sakit Muhammadiyah Palembang. Hal ini dilakukan mengingat Sumatera Selatan termasuk provinsi dengan jumlah kasus glaukoma yang tinggi di Indonesia sehingga data-data epidemiologi masih sangat diperlukan untuk membantu upaya perbaikan oleh dinas terkait.

\section{METODE}

Penelitian ini menggunakan data sekunder dari Rumah Sakit Muhammadiyah Palembang dengan jenis penelitian deskriptif retrospektif menggunakan pendekatan cross sectional. Jumlah populasi terjangkau adalah 82 subjek, dengan perhitungan menggunakan rumus diperoleh besar sampel sebesar 45 subjek. Sampel diambil dengan teknik simple random sampling. Variabel yang diteliti adalah usia, jenis kelamin, jenis glaukoma, keluhan utama saat datang ke dokter, tekanan intraocular, dan riwayat penyakit dahulu yang kemungkinan berisiko menimbulkan glaukoma.

Kriteria inklusi dalam memilih sampel adalah seluruh pasien glaukoma yang berobat ke Rumah Sakit Muhammadiyah Palembang pada periode Januari 2017-April 2018. Apabila pasien terpilih sebagai subjek namun data rekam 
medisnya yang tidak mencantumkan variabel penelitian ini secara lengkap, maka pasien tersebut dikeluarkan dari sampel penelitian. Data dianalisis secara univariat dan ditampilkan dengan tabel distribusi frekuensi.

\section{HASIL PENELITIAN}

Karakteristik penderita glaukoma di Rumah Sakit Muhammadiyah Palembang (RSMP) pada periode Januari 2017-April 2018 dirangkum dalam tabel 1.

Tabel 1. Karakteristik Penderita Glaukoma di Rumah Sakit Muhammadiyah Palembang ( $\mathrm{n}=45$ orang)

\begin{tabular}{lcc}
\hline \multicolumn{1}{c}{ Variabel } & N (orang) & $(\mathbf{\%})$ \\
\hline Usia (tahun) & 2 & 4,4 \\
$<40$ & 30 & 66,7 \\
$40-64$ & 13 & 28,0 \\
$\geq 65$ & & \\
Jenis kelamin & 19 & 42,4 \\
Laki-laki & 26 & 57,8 \\
Perempuan & & \\
Jenis glaukoma & 7 & 15,6 \\
Akut & 26 & 57,8 \\
Kronis & 12 & 26,7 \\
Absolut & 0 & 0,0 \\
Kongenital & & \\
Tekanan intraokular & & \\
(mmHg) & & 26,7 \\
$\leq 21$ & 12 & 73,3 \\
$>21$ & 33 & \\
Riwayat Penyakit & & 40,0 \\
Tidak ada & 18 & 60,0 \\
Ada & 27 &
\end{tabular}

Berdasarkan tabel 1, didapatkan hasil bahwa kategori usia 40-64 tahun lebih banyak menderita glaukoma dibandingkan pada usia lainnya $(66,7 \%)$. Pada karakteristik berdasarkan jenis kelamin, perempuan lebih banyak menderita glaukoma $(57,8 \%)$. Berdasarkan jenisnya, glaukoma kronis lebih sering terjadi dibandingkan jenis glaukoma lainnya (57,8\%). Pada penelitian ini, lebih banyak ditemukan penderita glaukoma dengan tekanan intraokular tinggi $(73,3 \%)$ dan memiliki riwayat penyakit terdahulu $(60 \%)$.

Tabel 2. Keluhan utama penderita Glaukoma

\begin{tabular}{lcc}
\hline \multicolumn{1}{c}{ Keluhan Utama } & N (orang) & \% \\
\hline Nyeri mata & 23 & 37,7 \\
Sakit kepala & 9 & 14,8 \\
Mata kabur & 18 & 29,5 \\
Mata merah & 3 & 4,9 \\
Mual muntah & 1 & 1,6 \\
Halo & 1 & 1,6 \\
Buta & 6 & 9,8 \\
Total & 61 & 100,0 \\
\hline
\end{tabular}

Keluhan utama yang dirasakan melebihi besar sampel yaitu 61. Hal ini disebabkan adanya 17 pasien yang memiliki gejala lebih dari satu. Keluhan yang paling sering dirasakan pasien adalah nyeri mata, lalu diikuti dengan mata kabur. Untuk keluhan seperti sakit kepala, mata merah, buta, mual muntah, dan adanya halo jarang dialami oleh pasien.

Tabel 2. Distribusi Frekuensi Riwayat Penyakit

\begin{tabular}{lcc}
\hline Riwayat penyakit & N (orang) & \% \\
\hline Kelainan lensa & 13 & 48,1 \\
Kelainan traktus & 1 & 3,7 \\
uvealis & 12 & 44,4 \\
Hipertensi & 0 & 0,0 \\
Hipotensi akut & 0 & 0,0 \\
Diabetes mellitus & 1 & 3,7 \\
Trauma mata & 0 & 0,0 \\
Miopia & 27 & 100,0 \\
Total & \multicolumn{2}{c}{ Berdasarkan data rekam medis, } \\
\multicolumn{2}{c}{ kelainan lensa yang didapatkan pada } \\
penelitian ini adalah katarak, sedangkan
\end{tabular}


kelainan traktus uvealis yang didapatkan adalah uveitis. Pada penelitian didapatkan katarak lebih sering terjadi pada pasien glaukoma dibandingkan penyakitpenyakit lainnya. Dengan total yang tidak terlalu berbeda, hipertensi juga merupakan riwayat penyakit terbanyak kedua setelah katarak.

\section{PEMBAHASAN}

\section{1) Usia}

Pada penelitian ini didapatkan usia 40-64 tahun lebih sering mengalami glaukoma. Menurut WHO 45-59 tahun termasuk ke dalam usia pertengahan dan 60-74 tahun termasuk ke dalam lanjut usia. Usia merupakan salah satu faktor risiko yang dapat menyebabkan glaukoma (Guedes dkk, 2011). Hasil penelitian ini bersesuaian dengan karakteristik pasien glaukoma di Poliklinik Mata Rumah Sakit Indera Provinsi Bali yang sebagian besar berusia 40-64 tahun (Pusvitasari \& Triningrat, 2018).

Usia yang menua menyebabkan penuaan jaringan serta lebih lama terpapar faktor risiko glaukoma (Krieglstein, 2008). Aliran humor aqueous semakin menurun seiring bertambahnya usia sehingga akan menyebabkan peningkatan tekanan intraokular (Newell, 2008). Secara khusus, peningkatan usia akan menyebabkan perubahan pada elastin dan kekakuan kolagen tipe I yang akan mengurangi fleksibilitas lamina cribrosa, sehingga mengurangi kekuatan dari akson sel retina ganglion bila adanya peningkatan tekanan intraokular. Oleh karena itu, saraf optik pada usia tua rentan kehilangan fungsi akibat kerusakan yang ditimbulkan oleh glaukoma (Vajaranant \& Pasquale, 2012).

Hasil penelitian ini didapatkan dua subjek penderita glaukoma yang berusia di bawah 40 tahun $(4,4 \%)$. Salah satunya berusia 8 tahun dengan riwayat trauma mata. Menurut Riordan \& Whitcher (2017), timbulnya glaukoma pada anakanak bisa disebabkan oleh glaukoma sekunder akibat trauma mata atau penyakit mata lainnya. Adanya darah pada bilik mata depan (hifema) akan menyumbat anyaman trabekular sehingga timbul peningkatan tekanan intraokular.

Subjek yang berusia 39 tahun, glaukoma kemungkinan disebabkan oleh riwayat penyakit sebelumnya atau proses penuaan. Tetapi dari hasil penelitian, subjek tidak memiliki riwayat penyakit sebelumnya, sehingga kemungkinan penyebab glaukoma pada subjek adalah proses penuaan. Proses penuaan biologis terjadi secara perlahan-lahan dan dibagi menjadi beberapa tahapan. Pada usia 3545 tahun termasuk ke dalam tahap transisi, yaitu mulai terjadi gejala 
penuaan yang dapat bermanifestasi pada berbagai penyakit (Pangkahila, 2014).

\section{2) Jenis Kelamin}

Teori mengenai jenis kelamin yang dikaitkan dengan peningkatan risiko glaukoma adalah masalah yang kontroversial (Krieglstein, 2008). Hal ini terlihat pada penelitian-penelitian berikut yang memiliki hasil berbeda. Penderita glaukoma di Rumah Sakit Moehammad Hoesin Palembang pada tahun 2006 didominasi oleh perempuan $(51,22 \%)$ sementara penderita glaukoma di Poliklinik Mata Rumah Sakit Indera Provinsi Bali didominasi oleh laki-laki (70\%) (Fidalia, 2006; Pusvitasari \& Triningrat, 2018)

Faktor-faktor yang menyebabkan wanita mendapatkan glaukoma adalah menopause dini, terlambat menarche, ooforektomi, peningkatan paritas, dan penggunaan kontrasepsi oral (Krieglstein, 2008; Dewundara dkk, 2017). Namun, berdasarkan teori estrogen memiliki efek neuroprotektif terhadap sel ganglion retina sehingga mencegah glaukoma. Hal ini karena estrogen meningkatkan jumlah serat kolagen di lamina cribrosa sehingga dapat mengurangi kompresi pada akson sel ganglion retina. Serat kolagen yang meningkat juga bisa meningkatkan fleksibilitas seluruh mata, yang akan menyebabkan penurunan tekanan intraokular (Krieglstein, 2008).

\section{3) Jenis Glaukoma}

Banyaknya subjek penelitian yang menderita Glaukoma kronis dalam penelitian ini sejalan dengan penelitian Fidalia (2006) di RS Mohammad Hoesin Palembang yang menemukan kasus glaukoma sudut terbuka (glaukoma kronis) sebanyak 56,10\%. Penelitian oleh Bright Focus Foundation di Amerika Serikat juga menemukan glaukoma kronis mendominasi dengan persentase 70\% dari penderita glaukoma (Bright Focus Foundation, 2014). Berdasarkan European Glaucoma Society (2014), glaukoma kronis merupakan neuropati optik progresif, dengan adanya perubahan karakteristik morfologi di nervus optik.

Jumlah kasus glaukoma absolut di Rumah Sakit Muhammadiyah Palembang berada di urutan kedua yaitu sebanyak 12 orang $(26,7 \%)$. Glaukoma absolut adalah glaukoma dengan kebutaan total disertai dengan nyeri. Penyebab lain yang dapat menyebabkan nyeri pada pasien buta adalah trauma, neoplasia, infeksi dan peradangan. Nyeri memiliki dampak negatif pada kualitas hidup pasien serta kemampuannya berfungsi secara produktif (Mulugeta, 2017).

Kerusakan saraf yang terjadi perlahan-lahan berlanjut pada penurunan penglihatan membuat penderita tidak akan menyadari dirinya sakit sampai telah terlambat. Glaukoma kronik dapat 
berkembang menjadi glaukoma absolut (Kemenkes RI, 2015).

\section{4) Keluhan Utama}

Keluhan utama seorang pasien glaukoma dapat lebih dari satu sehingga dalam penelitian ini didapatkan 61 keluhan utama, lebih banyak dari jumlah sampel yang hanya 45. Pada penelitian ini nyeri mata lebih sering dikeluhkan. Sejalan dengan penelitian Mahrani (2009) yang dilakukan di RSU. Dr. Pirngadi, keluhan utama terbanyak adalah nyeri pada mata $(41,2 \%)$. Nyeri mata pada penekan simpul-simpul saraf di daerah kornea akibat tekanan intraokular. Simpul saraf di daerah kornea ini merupakan cabang dari nervus trigeminus sehingga daerah sekitar mata yang juga dipersarafi oleh nervus trigeminus ikut terasa nyeri. Rasa nyeri pada mata ini menjalar sampai kepala sehingga menyebabkan sakit kepala ((Riordan \& Whitcher, 2017; Dian dkk, 2016). Nyeri mata juga bisa disebabkan oleh terjadinya inflamasi pada badan siliar akibat kerusakan epitel kornea atau uveitis (Japan Glaucoma Society, 2006).

\section{5) Tekanan Intraokular}

Hasil penelitian ini menunjukkan tekanan intraokuler lebih dari $21 \mathrm{mmHg}$ (tinggi) lebih sering terjadi dibandingkan tekanan intraokular kurang dari $21 \mathrm{mmHg}$ (normal). Tekanan intraokular merupakan faktor risiko terpenting pada penyakit glaukoma dan berbagai penelitian secara luas mendukung hal tersebut (Ismandari \& Helda, 2011). Pada penelitian di Rumah Sakit Indera Provinsi Bali didapatkan bahwa pada penderita glaukoma yang memiliki tekanan intraokular di atas normal $(\geq 21 \mathrm{mmHg})$ lebih banyak dibandingkan penderita dengan tekanan intraokular $<21 \mathrm{mmHg}$ (Pusvitasari \& Triningrat, 2018). Lalu pada penelitian Asicha (2011) di Rumah Sakit Umum dr. Soedarso juga didapatkan penderita glaukoma yang memiliki tekanan intraokular di atas nilai normal (>21 mmHg) pada mata kanan sebanyak 64,6\% dan yang dalam rentang nilai normal $(\leq 21 \mathrm{mmHg})$ sebanyak 35,4\%. Rachmawati (2014) menemukan bahwa di RS Khusus Mata Provinsi Sumatera Selatan tahun 2012 dan 2013, didapatkan 30 pasien glaukoma sekunder $(83,3 \%)$ dengan tekanan intraokuler $\geq 21$ mmHg. Peningkatan tekanan intraokular secara konsisten dikaitkan dengan prevalensi kejadian glaukoma sudut terbuka (glaukoma kronis) (European Glaucoma Society, 2014).

Peningkatan tekanan intraokular lebih sering ditemukan karena berperan dalam apoptosis sel ganglion retina. Adanya perubahan dinamika anyaman trabekular menyebabkan gangguan drainase dari humor aquosus yang menyebabkan terjadinya peningkatan 
tekanan intraokular (Agarwal dkk., 2009).

Namun, kelainan glaukomatosa pada diskus optikus atau lapang pandang dapat menyebabkan glaukoma meskipun tekanan intraokular di bawah $21 \mathrm{mmHg}$. Hal ini dikenal sebagai glaukoma tekanan rendah (Riordan \& Whitcher, 2017).

\section{6) Riwayat Penyakit}

Ada atau tidak adanya riwayat penyakit, dapat menentukan jenis glaukoma apa yang dimiliki pasien. Apabila pasien tersebut tidak memiliki riwayat penyakit maka termasuk dalam glaukoma primer. Sedangkan pada pasien yang memiliki riwayat penyakit yang mungkin menyebabkan glaukoma disebut sebagai glaukoma sekunder. Hasil penelitian ini sejalan dengan penelitian Pusvitasari \& Triningrat (2018) yang menemukan bahwa jenis glaukoma yang paling banyak adalah glaukoma sekunder.

Tabel 2 menunjukkan riwayat penyakit terdahulu adalah kelainan lensa dan hipertensi. Kelainan lensa yang paling banyak terjadi adalah katarak. Pembengkakan lensa akibat katarak akan mendorong iris ke depan sehingga bilik mata dangkal dan sudut bilik mata akan tertutup. Hal ini menimbulkan glaukoma fakamorfik (Thayeb dkk., 2013). Hipertensi menjadi riwayat penyakit terbanyak kedua pada pasien glaukoma di penelitian ini. Insufiensi vaskular telah dilaporkan sebagai faktor risiko yang berpotensi untuk menimbulkan glaukoma. hipertensi sistemik merupakan faktor risiko untuk glaukoma (Bae dkk., 2014).

\section{SIMPULAN}

Hasil penelitian ini menunjukkan glaukoma lebih banyak terdistribusi pada kelompok usia 40-64 tahun $(66,7 \%)$ dan jenis kelamin perempuan $(57,8 \%)$. Tipe glaukoma didominasi oleh glaukoma kronis (57,8\%), dengan keluhan utama terbanyak berupa nyeri mata $(37,7 \%)$, memiliki tekanan intraokular lebih dari $21 \mathrm{mmHg}(73,3 \%)$, dan memiliki riwayat penyakit terdahulu yang dapat memicu glaukoma $(60,0 \%)$.

\section{DAFTAR PUSTAKA}

Agarwal R, Gupta SK, Agarwal P, Saxena R, \& Agrawal SS. 2009. Current Concepts in The Pathophysiology of Glaucoma. Indian Journal of Ophthalmology, 57(4): 257-266.

Asicha N. 2011. Karakteristik Penderita Glaukoma di Rumah Sakit Umum Dr. Soedarso Pontianak Tahun 2009-2010. Jurnal Mahasiswa PSPD FK Universitas Tanjungpura, 1(1): 1-17.

Bae HW, Lee N, Lee HS, Hong S, Seong GJ, \& Kim CY. 2014. Systemic hypertension as a risk factor for open-angle glaucoma: A metaanalysis of population-based studies. PLoS ONE, 9(9): 1-9.

Bright Focus Foundation. 2014. Glaucoma: The Essential Facts. Washington DC: National Glaucoma Research. Hal. 3-10. 
Dewundara S, Wiggs J, \& Sullivan DA. 2017. Is Estrogen a Therapeutic Target for Glaucoma? HHS Public Access, 31(1):140-146.

Dian E, Sari Y, \& Aditya M. 2016. Glaukoma Akut dengan Katarak Imatur Okuli Dekstra et Sinistra. J Medula Unila, 4(3):46-51.

European Glaucoma Society. 2014. Terminology and Guideline for Glaucoma. $\mathrm{Br} \mathrm{J}$ Ophthalmol, 101(5):73-127.

Fidalia. 2006. Prevalensi dan Faktor Resiko Glaukoma Primer Sudut Terbuka Serta Penatalaksanaannya di Bagian Mata FK UNSRI/RSMH Palembang. Palembang: Fakultas Kedokteran Universitas Sriwijaya [Skripsi].

Guedes G, Tsai J, \& Loewen N. 2011. Glaucoma and Aging. Current Aging Science, 4(2): 110-117.

Ismandari $\mathrm{F}$ dan Helda. 2011. Kebutaan pada Pasien Glaukoma Primer di Rumah Sakit Umum Dr. Cipto Mangunkusumo Jakarta. Jurnal Kesehatan Masyarakat Nasional, 5(4):185-192.

Japan Glaucoma Society. 2006. Guidelines for Glaucoma Edisi ke-2. Japan: Japan Glaucoma Society.

Kementerian Kesehatan Republik Indonesia. 2014. Situasi Gangguan Penglihatan dan Kebutaan. Jakarta: Kementerian Kesehatan RI.

Krieglstein GK. 2008. Essentials in Ophthalmology: Glaucoma. United States: $\quad$ Spinger Publishing Company. Hal. 13-21.

Mahrani HH. 2009. Karakteristik Penderita Glaukoma Di RSU. Dr.Pirngadi Medan Tahun 2007. Sumatera Utara: Fakultas Kesehatan Masyarakat Universitas Sumatera Utara [Skripsi].

Mulugeta A. 2017. Management of Absolute Glaucoma: Experience of Ras Desta Damtew Hospital, Addis Abeba, Ethiopia. Ethiop Med J, 55 (2):109-113.
Newell F. 2008. Ophtalmology. St. Louis: Mosby. Hal.230-250.

Pangkahila A. 2014. Pelatihan Fisik Seimbang Meningkatkan Aktivitas Stem Cell Endogen Untuk Anti Penuaan. Sport and Fitness Journal, 2(1):1-9.

Pusvitasari LW \& Triningrat AAMP. 2018. Profil pasien glaukoma di Poliklinik Mata Rumah Sakit Indera Provinsi Bali Periode Januari 2014-Juni 2015. E-Jurnal Medika Udayana, 7(4):189-193.

Putri PGAB, Sutyawan IWE, \& Triningrat 2018. Karakteristik Penderita Glaukoma Primer Sudut Terbuka dan Sudut Tertutup di Divisi Glaukoma di Poliklinik Mata Rumah Sakit Umum Pusat Sanglah Denpasar periode 1 Januari 2014 hingga 31 Desember 2014. E-Jurnal Medika, 7(1):16-21.

Rachmawati D. 2014. Karakteristik Pasien Glaukoma Sekunder di Rumah Sakit Khusus Mata Provinsi Sumatera Selatan Tahun 2012 dan 2013. Skripsi. Palembang: Fakultas Kedokteran Universitas Muhammadiyah Palembang [Skripsi]. Hal.67-68.

Riordan P \& Whitcher JP. 2017. Oftalmologi Umum Edisi ke-17. Jakarta: Penerbit Buku Kedokteran EGC. Hal 212-229.

Thayeb DA, Saerang JS, \& Rares LM. 2013. Profil Glaukoma Sekunder Akibat Katarak Senilis Pre-Operasi di RSUP. Prof. Dr. R.D. Kandou Manado Periode Januar 2011Desember 2011. Jurnal EBiomedik, 1(1):59-63.

Vajaranant T \& Pasquale L. 2012. Estrogen Deficiency Accelerates Aging of The Optic Nerve. Menopause, 19(8): 942-947.

World Health Organization. 2012. Global Data on Visus Impairments 2010. Switzerland: World Health Organization. 